\title{
Cloned mice fail to rekindle ethics debate
}

[WASHINGTON] Just over a year ago, the US Congress was in ferment over proposals to enact legislation outlawing human cloning, following the cloning of Dolly the sheep. But little has happened since, and legislators seem unlikely to take immediate action in the wake of the announcement last week that Hawaiian scientists have made dozens of mouse clones, a species previously thought to pose prohibitive biological obstacles (see Nature 394, 369; 1998).

The report, which drew predictions that human cloning may be much nearer than expected, has provoked muted reaction from Congress, the White House and the National Bioethics Advisory Commission (NBAC), which had all previously called for human cloning to be either outlawed or subject to a legislated moratorium.

"The president's position has not changed," says Estela Mendoza, a White House spokeswoman. "He still believes it's morally unacceptable for anyone in either the public or private sector to attempt to produce a human being using somatic cell nuclear transfer technology."

Harold Shapiro, president of Princeton University and NBAC chairman, says the work presents "no reason to be alarmed", but should spur intense ethical discussions.

In Congress, a tight legislative schedule before October's recess, combined with a split between libertarian and socially conservative Republicans on the advisability of outlawing cloning, is likely to forestall any imminent action.

This is good news for many biomedical research advocates, who have backed volun-

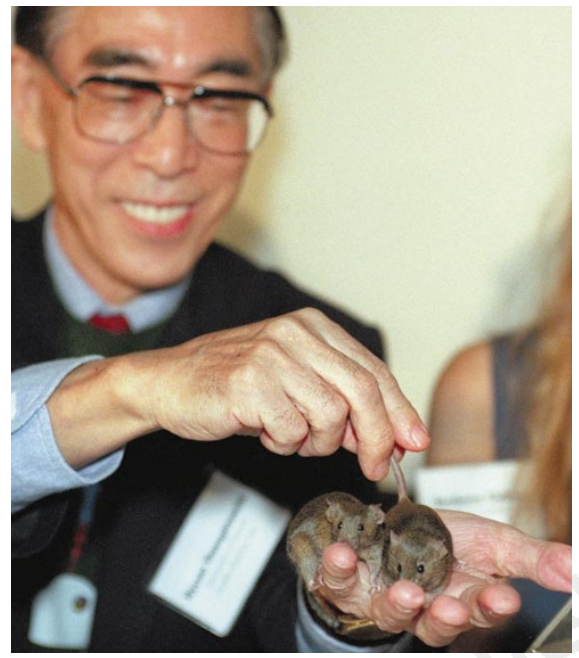

Double or quit? Not everyone shares Dr Ryuzo Yanagimachi's delight in his cloning success.

tary moratoria on cloning, fearful that a law could unduly restrict research. Shapiro agrees: "We're much better off without legislation than with bad legislation."

No law currently prohibits privately financed human cloning in the United States, although federal funding is prohibited under a broader ban on government funding for human embryo research.

There is a deep division between moderate and conservative Republicans in the Senate, the former not wanting to constrain research, the latter demanding a criminal ban on the production of cloned embryos, whether for research or implantation.

Bill Frist (Republican, Tennessee), a physician who earlier this year co-authored a bill that would have criminalized human cloning, whether or not cloned embryos are implanted, describes the news of the cloned mice as "predictable" but says "this just probably cut by 50 per cent the length of time to clone a human being".

Asked at a Senate news conference whether Congress should act on his bill which was shelved in February after lobbying by biomedical research advocates and fertility physicians (see Nature 391, 730, 1998) — he called instead for Congress to pass another bill he has authored.

This calls only for the establishment of a national bioethics commission to discuss cloning among other issues. It would allow Congress to act intelligently and "not be forced to react and respond to the latest news event".

NBAC last year recommended a threeto-five-year moratorium on human cloning, basing its arguments on safety considerations (see Nature 387, 644; 1997). This drew complaints from conservative Republicans, who said a permanent ban was needed because moral considerations make cloning unacceptable.

Edward Kennedy (Democrat, Massachusetts), co-author with Dianne Feinstein (Democrat, California) of another Senate bill, says the news changes nothing in terms of the approach to policy. Kennedy's bill would impose a ten-year moratorium on human cloning, but not on the production of cloned embryos that are not implanted. As such, it "represents the best public policy", Kennedy said last week.

The leading author of anti-cloning legis-

\section{Japanese fear that new publicity rules could hinder their research}

[TOKYO] Japanese scientists are concerned that proposed regulations on cloning could jeopardize the international impact of their work.

An interim report released in June by the Science and Technology Council expresses support for the advancement of cloning technology (see Nature $393,726 ; 1998)$. But as well as calling for the strict regulation of human cloning, it requires information about all mammalian cloning research to be made public before the animal is born.

The report, to be finalized by autumn, says researchers are not expected to release information that could undermine their intellectual property rights. But it does not specify precisely when they are to release their information. Scientists will be expected to report their plans in advance to the government, which will make a public announcement to stimulate awareness and understanding of cloning technologies.

Researchers carrying out projects funded by the Ministry of Agriculture, Fisheries and Forestry (MAFF) will be required to announce the contents of their research activities a hundred days after implantation.

But several researchers are concerned that these regulations would make it impossible for them to conceal the birth of cloned animals until publication in scientific journals. They see this as a significant disadvantage, as researchers outside Japan are not subject to such restrictions.

Yukio Tsunoda, a professor in mammalian embryology at Kinki University who was responsible for the cloning of twin calves earlier this month (see Nature 394,114 ; 1998), says he feels under pressure because the paper he is writing about it will be published months after the animals were born.

The calves, produced by scientists at Kinki University and Ishikawa Prefecture Livestock Research Centre, are claimed to be the second large mammals cloned from adult somatic cells. The team used cells from the oviducts of an adult cow.

Apart from the fact that the project was funded by MAF,
Tsunoda says his decision to announce the births of the calves reflects the government's call for the disclosure of scientific information on cloning.

Although news of the cloned calves was welcomed by the scientific community in Japan, the lack of detailed information gave rise to some scepticism among overseas researchers. One cloning expert says he still has no idea of the techniques or type of cells used in the work.

The twin calves, named Noto and Kaga, will soon be joined by many others. MAFF has recently revealed that a total of 29 cloned calves - including eight from Tsunoda's research groups - are expected to be born by the end of the year.

Asako Saegusa 
lation in the House, Vern Ehlers (Republican, Michigan), says temporal and political constraints will almost certainly block action this year. He says "there are not enough votes" to move his bill out of the health and environment subcommittee of the House Commerce Committee where it is stalled. His bill would ban federal funding for producing cloned human embryos, whether or not they are implanted.

The Biotechnology Industry Organization (BIO), which backs a voluntary moratorium, says it has not changed its position. "BIO stands against the use of this technology to clone human beings," said Carl Feldbaum, BIO's president, in a statement. It says the Food and Drug Administration (FDA) can block cloning under existing federal regulations, a position the FDA itself asserted in January after Richard Seed, a Chicago physicist, vowed to clone a human.

"If you can clone from mice, humans should be easier," says Lee Silver, professor of genetics at Princeton University and author of Remaking Eden: Cloning and Beyond in a Brave New World. "It's going to be used by [a small percentage of infertile] people to have biological children, period," Silver says. "That's the only way it's ever going to be used. And I have no problem with that."

But Robert Edwards, the British pioneer with the surgeon Patrick Steptoe of in vitro fertilization, says infertility does not justify cloning. Edwards, who last week endorsed the idea that the test-tube embryos of infertile couples be cloned in difficult cases to improve the chances of implantation, says that the use of cloning in infertility treatment should stop there.

"Many people would say it's the thin end of the wedge," Edwards concedes. But, he adds, "nobody's worth cloning... I can't think of anybody even to mention apart from the Lord Himself."

MeredithWadman

\section{Patent clash looming over cloning techniques?}

[PARIS] A clash over patent rights to the technology of cloning by nuclear transfer seems on the cards, following an application for patents by the University of Hawaii and ProBio America Inc, a

Honolulu-based biotechnology company, on the technology behind last week's report on the reproducible cloning of mice.

The Roslin Institute in Scotland, which cloned the sheep Dolly two years ago and has two broad patent applications pending covering cloning techniques, says that if it feels that the new claims infringe these it will challenge them.

"We will defend our intellectual property position vigorously," says Harry Griffin, assistant director of the Roslin Institute. He emphasized that the precise claims in the new patent application are not yet clear.

To produce Dolly, an adult cell was fused with an enucleated oocyte by electrofusion and the reconstructed embryo was simultaneously activated. The Honolulu group says the novelty of its method is in directly microinjecting the nucleus into an enucleated egg and activating the egg later -a step claimed to partly explain the improved success rate (see
Nature 39 4, 369; 1998).

But Griffin says: "I don't

think that injection of a nucleus

rather than cell fusion, or the

delay in activation, is novel." He adds that the Roslin patent applications cover "all

quiescent cells", so include the cumulus cells used by the Hawaiian researchers. "We believe we have a very strong patent position," says Griffin.

No details of the Hawaiian application have been made

public. The University of Hawaii declines to comment in detail on its application, saying that this is "proprietary information".

Andrew Sheard, a patent attorney at London-based Kilburn \& Strode, which is handling the Dolly patents, says: "It seems to us that the Hawaiian group have made a refinement of the basic technology." He says the Roslin patents cover cloning broadly, in that they claim "a method of reconstituting the embryo comprising transferring the nucleus of a quiescent donor cell into a suitable recipient cell".

Meanwhile, UK company Protein Pharmaceuticals Limited (PPL) has moved swiftly to negotiate a licence on the ProBio America technology for research into the cloning of pigs and other farm animals. The company has already agreed to take a licence on cloning technology from the Roslin Institute. But this only covers "production of proteins for pharmaceutical and nutriceutical use in the milk of ruminant livestock or rabbits".

Roslin has exclusively licensed rights for all other biomedical applications of genetically modified livestock, including use of pig organs as human transplants, to Roslin

Biomed, a company set up with f6 million (\$9.9 million) from the venture capital company $3 \mathrm{i}$.

PPL, which has a

substantial research effort in xenotransplants - a potential market of $\$ 6$ billion (see Nature 39 1,315; 1998) - sees the Honolulu patent as a route into pig cloning. "The potential of cloning for breeding animals, and in particular pigs, for xenotransplantation, is certainly the major reason for interest," says Ron James, chief executive officer of PPL.

PPL has no access to the Roslin technique for xenotransplantation research, and James argues that the Hawaiian technique seems more promising for pigs.

"Ultimately, he says, one may need both the Roslin techniques and those of the Hawaiian researchers." DeclanButler

\section{Mother bears could help save giant panda}

[токуо] Global efforts at cloning do not stop at familiar animals such as sheep, cows and mice. Scientists in China are planning to attempt to clone the country's national symbol, the giant panda, in a desperate bid to save the animal from extinction. But other researchers are sceptical about their chances of success.

Last week, scientists from China's National Academy of Sciences announced a project to clone the giant panda by 2003. They are hoping to transfer the nucleus from an adult giant panda cell into the egg of another species, perhaps a black bear. The hybrid egg would be induced to differentiate before being implanted into the uterus of a foster mother of the second species.

The researchers say the advantage of such a technique is that only a few panda cells would be needed to produce an embryo. Such 'trans-species' cloning would also avoid using panda eggs, which - with only 1,000 pandas left in the world — are rare and difficult to harvest.

Chen Dayuan, the leader of the project and a professor of zoology at the academy, expressed his confidence, during an interview with China Central Television, that cloning could become an effective method to breed pandas, and that Chinese scientists would be the first to succeed with such an experiment.

But international experts in cloning have doubts about the chances of success, pointing out that cross-species cloning is unlikely to work unless the eggs and the genetic material are taken from closely related species.

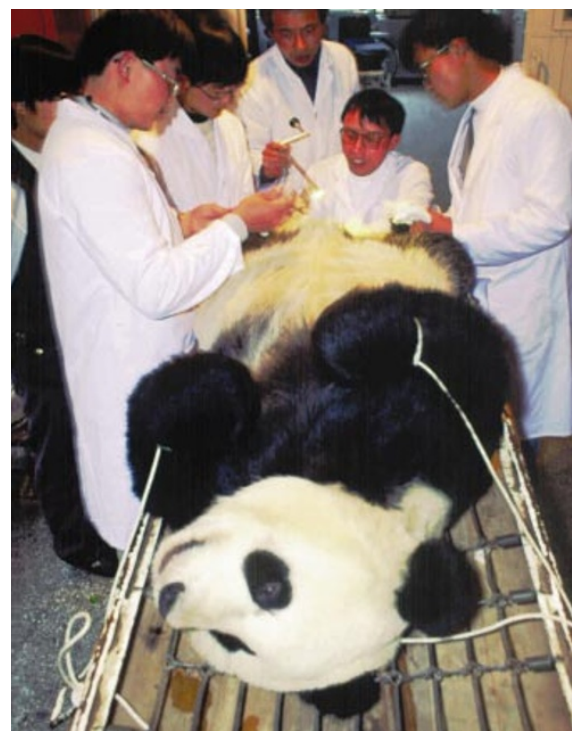

Making babies: artificial insemination attempt 